\title{
PENGARUH PENGGUNAAN MEDIA GRAFIS KOMIK TERHADAP PRESTASI BELAJAR IPA PADA MATERI FUNGSI ALAT-ALAT TUBUH SISWA KELAS V SLB B
}

\author{
Irfan Pratama, Gunarhadi*, Priyono
}

Pendidikan Luar Biasa FKIP Universitas Sebelas Maret Surakarta

\begin{abstract}
This research aims at finding out the effect of using comic graphic media on the achievement of learning Science for the hearing-impaired students. The method used in this research is One-group Experiment with Pretest- Posttest Design. The population is six hearing-impaired students at class V of the extraordinary school (SLB B) Karanganyar. Test is used for collecting the data, while the data are analyzed by using nonparametric statistics, that is, Wilcoxon Signed Rank Test with SPSS version 20. The result shows that the mean score of posttest, 93.33, is greater than the mean score of pretest, 51.67. Based on nonparametric analysis, it is found that $\mathrm{Z}$ score is -2.232 , and $\mathrm{P}$ is 0.026 . Thus, hypothesis saying that there is significant effect of using comic graphic media on the achievement of learning Science for the hearing-impaired students is accepted. It implies that the use of comic graphic media has significant effect on the achievement of learning Science for the hearing-impaired students at class V of the extraordinary school (SLB B) Karanganyar.
\end{abstract}

Key words: comic graphic media, achievement of learning Science, hearing-impaired students

\begin{abstract}
Abstrak: Penelitian ini bertujuan untuk mengetahui pengaruh penggunaan media grafis komik terhadap prestasi belajar IPA siswa kelas V di SLB B. Metode penelitian menggunakan metode eksperimen dengan rancangan One Group Pretest- Posttest. Populasi penelitian ini adalah 6 siswa tunarungu kelas 5 di SLB-B Karanganyar. Teknik pengumpulan data menggunakan teknik tes. Analisis data menggunakan teknik analisis statistik non-parametrik, yaitu Wilcoxon Signed Rank Test dengan bantuan SPSS versi 20. Hasil penelitian disimpulkan bahwa hasil analisis deskriptif diperoleh nilai rata-rata posttest sebesar 93,33 > nilai rata-rata pretest sebesar 51,67 dan hasil analisis nonparametric diperoleh nilai $Z=-2.232$ dengan $P=0,026$. Dengan demikian, hipotesis "Ada pengaruh signifikan penggunaan media grafis komik terhadap prestasi belajar IPA siswa tunarungu" diterima kebenarannya. Ini berarti, penggunaan media grafis komik memiliki pengaruh signifikan terhadap prestasi belajar IPA siswa tunarungu di kelas V di SLB-B Karanganyar.
\end{abstract}

Kata kunci: media grafis komik, prestasi belajar IPA, anak tunarungu

Alamat korespondensi: Jalan Ir. Sutami 36 A. FKIP. Universitas Sebelas Maret. Surakarta. e-mail: gunarhadi@fkip.uns.ac.id. 


\section{PENDAHULUAN}

Ilmu Pengetahuan Alam atau IPA merupakan bagian yang penting dalam bidang pendidikan. Segala hal tentang kaidah-kaidah dasarnya dapat membimbing manusia untuk berhubungan dengan alam dan segala kebendaannya. Hal ini sesuai apa yang dikemukakan oleh Trianto (2010:136), bahwa Ilmu Pengetahuan Alam adalah pengetahuan yang sistematis dan dalam perumusannya berhubungan dengan gejala-gejala kebendaan serta didasarkan atas pengamatan dan deduksi.

Pada umumnya, pembelajaran sains di sekolah terbagi menjadi dua bagian besar, yaitu sains sebagai produk dan sains sebagai proses. Sains sebagai produk adalah pada pengajaran tentang fakta, teori, prinsip, dan hukum alam. Sedangkan Sains sebagai proses adalah pengembangan kemampuan siswa dalam metode ilmiah dan pengembangan masalah Sains. Proses pembelajaran IPA menekankan pada pemberian pengalaman langsung untuk mengembangkan kompetensi agar mampu menjelajahi dan memahami alam sekitar secara ilmiah dalam pemecahan masalahnya. Menurut Winaputra dalam Samatowa, 2011: 3), IPA tidak hanya merupakan kumpulan pengetahuan tentang benda atau makhluk hidup, tetapi memerlukan kerja, cara berpikir, dan cara memecahkan masalah.

Potensi kecerdasan anak tunarungu tidak begitu jauh jika dibandingkan dengan anak normal. Namun, secara fungsional perkembangannya dipengaruhi oleh tingkat kemampuan berbahasa dan keterbatasan informasi. Akibat dari keterbatasan kemampuan bahasa dan keterbatasan informasi karena faktor ketunarunguannya, anak tunarungu menjadi semakin kesulitan memahami konsep dasar materi, terlebih untuk berprestasi di bidang sains.

Menurut Sadja'ah (2013:48), karakteristik anak tunarungu dilihat dari implikasi ketunarunguannya dapat dibedakan menjadi 4 aspek, yaitu:(1) Aspek bahasa dan berbicara, dampak dari ketunarunguan sangat berpengaruh pada perkembangan bahasa anak yang terhambat dan keterampilan berbicara terhambat pula; (2) Aspek intelegensi, anak tunarungu memiliki kemampuan intelegensi potensial setara dengan anak normal. Akan tetapi karena faktor ketunarunguannya tersebut, pendengaran mereka terhambat dalam masukan bahasa. Dari aspek motorik umumnya berkembang dengan baik. Namun ada beberapa anak yang kurang memiliki 
keseimbangan gerak akibat gangguan pendengarannya; (3) Aspek sosial, dalam aspek ini kematangan sosial anak tunarungu mengalami keterlambatan karena kurangnya berkomunikasi dengan orang lain. Hal ini dapat diatasi dengan menanamkan sedini mungkin nilai-nilai sosial pada anak, memberi kesempatan anak mendapatkan pengalaman baru dari lingkungan, membiasakan berkomunikasi dengan anak, dan memberi arahan yang cukup jelas bagi anak tunarungu, dan (4) Aspek kepribadian, anak tunarungu memiliki keterbatasan dalam mempersepsikan rangsangan emosi seperti marah atau gembira sehingga anak tunarungu sering memperlihatkan sikap curiga, agresif, kurang empati, dsb.

Media pembelajaran dibutuhkan untuk memberikan kemudahan bagi anak tunarungu mendapatkan akses informasi terkait mata pelajaran IPA. Media pembelajaran kaitannya dengan IPA atau Sains bagi anak tunarungu, harus mempunyai sebuah ciri khas tersendiri. Ciri khas tersebut dalam kehadirannya disesuaikan dengan kecenderungan anak tunarungu yang optimal dari aspek visualnya. Media pembelajaran yang dipakai adalah media grafis komik. Komik dalam penggunaannya sangat dipengaruhi oleh faktor visual pembacanya.
Pengertian tentang komik dikemukakan salah satunya oleh Masdiono (1998:3), yaitu komik merupakan susunan gambar bercerita dan memberikan pesan-pesan kepada pembacanya.

Kecenderungan utama siswa tuna rungu adalah dengan optimalnya potensi visual yang mereka miliki. Hal inilah yang harus dimanfaatkan dalam pemberian media pembelajaran kepada mereka. Menurut Avriliyanti (2012:3), kelebihan dari komik pembelajaran dalam aspek visualnya adalah (1) Media visual dapat memperlancar pemahaman dan memperkuat ingatan, (2) Visual dapat pula menumbuhkan minat siswa dan dapat memberikan hubungan antara isi materi pelajaran dengan dunia nyata, (3) Kualitas gambar komik dapat meningkatkan kualitas pembelajaran.

Komik jika dilihat dari aspek kontekstualitas konten akan mempunyai tujuan untuk menyampaikan pesan sesuai muatan materi yang diajarkan. Kontekstualitas dalam alur cerita dibuat atau dikonsep dengan melihat lingkungan anak. Kontekstualitas dihadirkan dari adegan maupun percakapan yang dilakukan oleh karakter dalam komik. Pendekatan kontekstualitas tersebut digunakan agar anak bisa secara penuh melibatkan dirinya dalam pembelajaran. 
Hal tersebut sesuai dengan pendapat Sanjaya bahwa pendekatan kontekstualitas adalah suatu strategi pembelajaran yang menekankan kepada proses keterlibatan siswa secara penuh untuk memahami materi yang dipelajari dan menghubungkan dengan situasi kehidupan nyata sehingga mendorong siswa untuk dapat menerapkannya dalam kehidupan mereka (2008:253).

Antusiasme dalam belajar adalah suatu hal yang perlu dimunculkan. Hanya saja, terkadang hal tersebut menjadi sulit karena antusiasme merupa-kan faktor internal siswa. antusiasme saat belajar akan mempengaruhi sikap siswa terhadap kesiapan menerima pelajaran. Maka dari itu media pem-belajaran dibuat dan disesuaikan dengan faktor perkembangan siswa agar mempengaruhi antusiasme mereka. Komik dibuat sesuai usia perkembangan seorang anak agar turut serta mempengaruhi perkembangan imajinasi dan kepribadian anak. Penggabungan antara faktor dunia anak dengan fungsi media pembelajaran ini diharapkan bisa membuat siswa tunarungu lebih ceria dengan IPA dan menuntun anak memahami pesan-pesan dari materi secara komprehensif. Komik pembelajaran dalam teknologi pendidikan bersifat edukatif dan menciptakan unsur penyampaian pesan yang jelas serta komunikatif (Novianti dan Syaichudin, 2010:77).

Penelitian ini dilaksanakan di SLB-B Pawestri Karanganyar. Komik IPA yang digunakan dalam penelitian ini dikembangkan sesuai kemampuan dari siswa kelas 5 di SLB-B Pawestri Karanganyar tahun ajaran 2014-2015. Kemampuan yang dimaksud adalah tingkat pemahaman bahasa yang dikuasai anak. Bahasa yang digunakan dalam komik ditentukan dengan tingkat pemahaman bahasa mereka.

\section{METODE PENELITIAN}

Penelitian ini menggunakan pendekatan kuantitatif dengan metode eksperimen. Penelitian ini menggunakan desain prates-pascates satu kelompok (one group pretest-posttest design) sekelompok subjek diberikan perlakuan (metode kata lembaga) dalam jangka waktu tertentu. Pengukuran dilaksanakan sebelum dan sesudah perlakuan diberikan, perbedaan antara hasil pengukuran awal $\left(T_{1}\right)$ dengan hasil pengukuran akhir $\left(\mathrm{T}_{2}\right)$ merupakan pengaruh dari perlakuan yang diberikan. 
Dalam penelitian ini mengambil populasi siswa kelas 5 (lima) SLB B Pawestri Karanganyar. Pengambilan sampel pada penelitian ini menggunakan teknik sampling jenuh. Menurut Sugiyono (2013: 70), "Sampling jenuh adalah teknik pengambilan sampel dengan menjadikan semua anggota populasi sebagai sampel”. Hal ini dikarenakan jumlah anggota populasi yang relatif sedikit, yakni siswa SLB-B Pawestri Karanganyar kelas 5 yang seluruhnya berjumlah 6 orang.

Variabel bebas dalam penelitian ini adalah penggunaan media pem-belajaran grafis komik. Variabel terikat dalam penelitian ini adalah adalah prestasi belajar IPA siswa tunarungu pada materi fungsi alat-alat tubuh kelas 5 di SLB-B Pawestri Karanganyar tahun ajaran 2014/2015. Metode pengumpulan data yang digunakan dalam penelitian ini adalah metode tes. Dalam penelitian ini, penulis menggunakan tes yang berbentuk pilihan ganda. Tes tersebut dibuat sendiri dan divalidasi oleh 2 ahli.

Penelitian ini menggunakan validitas isi (content validity) karena instrumen penelitian yang berupa test, untuk instrumen yang akan mengukur efektivitas pelaksanaan program, maka pengujian validitas isi dapat dilakukan dengan membandingkan antara isi instrumen dengan isi atau rancangan yang telah ditetapkan. Penelitian ini juga menggunakan jenis face validity (validitas muka) dengan melibatkan para ahli, yaitu ahli bahasa, ahli materi dan ahli media.

Teknik analisis data hasil penelitian ini menggunakan teknik analisis kuantitatif. Penelitian ini menggunakan teknik non parametrik yaitu teknik analisis tes Uji Rangking Bertanda Wilcoxon (Wilcoxon Sign Rank Test) yang diberi simbol $\mathrm{T}$.

\section{HASIL DAN PEMBAHASAN}

\section{Hasil Penelitian}

Untuk mengetahui bagaimana pengaruh media pembelajaran tersebut, maka dibutuhkan data sebagai bahan analisis. Data diperoleh dari hasil pretest yang didapat dari nilai tes sebelum dilakukan treatment dan post-test yang didapat dari nilai tes setelah dilakukan treatment, yang dapat dilihat dalam tabel 1.

Selanjutnya data-data tersebut dianalisis menggunakan statistik non parametrik dengan analisis uji Wilcoxon Signed Rank Test dan menggunakan 
program pengolahan data statistik SPSS

20.

Tabel 1 Data Nilai Pretest dan Posttest.

\begin{tabular}{lll}
\hline $\begin{array}{l}\text { No } \\
\text { Subjek }\end{array}$ & Nilai Pretest & $\begin{array}{l}\text { Nilai } \\
\text { Postest }\end{array}$ \\
\hline 1 & 70 & 100 \\
2 & 60 & 100 \\
3 & 50 & 90 \\
4 & 40 & 90 \\
5 & 40 & 80 \\
6 & 50 & 100 \\
\hline
\end{tabular}

Hasil analisis menunjukkan adanya pengaruh yang signifikan dari penggunaan media grafis komik terhadap prestasi belajar IPA siswa tunarungu pada materi fungsi alat-alat tubuh kelas V di SLB-B Pawestri Karanganyar tahun ajaran 2014/2015.

Pengujian persyaratan analisis dilakukan dengan membandingkan Asymp.Sig (2-tailed) dengan taraf signifikansi $(\alpha)$ agar dapat diketahui keputusan ditolak atau diterimanya hipotesis. Berdasarkan analisis nilai pretest dan posttest diperoleh nilai Asymp.Sig (2-tailed) $=0.026<0.05$ maka hipotesis diterima.

Komik pembelajaran dalam teknologi pendidikan bersifat edukatif dan menciptakan unsur penyampaian pesan yang jelas serta komunikatif (Novianti dan Syaichudin, 2010:77).
Oleh karena itu, dengan adanya media pembelajaran grafis dalam bentuk komik dapat mempermudah dalam penyampaian materi pelajaran. Komik akan menjadi media yang efektif apabila dalam pembuatannya tetap dalam pemahaman akan tujuan utamanya yaitu me-nyampaikan informasi/ pesan.

Keunggulan komik ketika dilihat dari segi visual menjadi nilai plus ketika dijadikan alternatif media pembelajaran bagi anak tuna rungu. Anak tunarungu memiliki kecenderungan yang dominan dari aspek visualnya. Gambar karaker yang ditawarkan oleh komik diperjelas dengan percakapan yang memuat serta materi IPA di dalam pembuatannya. Percakapan tersebut diletakkan dalam balon kata yang diperankan oleh karakter atau tokoh dalam komik. Balon kata dalam komik menjadi salah satu kunci penting dalam memberikan penjelasan kaitan antara materi dengan konsep nyatanya.

Fungsi komik sebagai media pembelajaran dibuktikan dengan adanya keselarasan dengan teori yang dikemukakan Levie dan Lentz dalam Arsyad (2007: 16-17) tentang empat fungsi media pembelajaran, khususnya media visual, yaitu: 
a. Fungsi atensi, media visual merupakan inti, yaitu menarik dan mengarahkan perhatian siswa untuk berkonsentrasi pada isi pelajaran yang berkaitan dengan makna yang ditampilkan dalam materi pelajaran.

b. Fungsi afektif, fungsi media visual dapat terlihat dari tingkat ke-nikmatan siswa, menggugah perasaan, respon ketika proses belajar mengajar berlangsung. Media pembelajaran yang tepat guna dapat meningkatkan sambutan atau penerimaan siswa terhadap stimulus yang diberikan.

c. Fungsi kognitif, media visual dapat mengungkapkan bahwa lambang visual atau gambar memperlancar pencapaian tujuan untuk memahami dan mengingat informasi atau pesan yang terkandung dalam gambar.

d. Fungsi kompensatoris, fungsi media adalah untuk mengakomodasikan siswa yang lemah dan lambat menerima dan memahami isi pelajaran yang disaji dengan teks atau disajikan secara verbal.

Fungsi atensi dari penggunaan media pembelajaran komik ditunjukkan dengan temuan bahwa anak menjadi lebih fokus terhadap materi ketika pembelajaran berlangsung. Maka dari itu komik sebagai media pembelajaran mampu menarik dan mengarahkan perhatian siswa untuk berkonsentrasi pada isi pelajaran yang berkaitan dengan makna yang ditampilkan dalam materi pelajaran

Sementara itu temuan dari fungsi afeksi juga bisa ditunjukkan dengan peningkatan siswa yang menjadi lebih bisa menghargai pendapat teman yang lain. Ketika dalam pembelajaran dan kemudian ada pertanyaan, peneliti tidak langsung menjawab pertanyaandari siswa, akan tetapi memberikan kesempatan kepada teman yang lain untuk menjawab terlebih dahulu. Dalam bertanya terkadang ada beberapa kata yang belum mereka ketahui yang selanjutnya mendorong mereka untuk bertanya tentang maksud kata tersebut. Bahkan ketika ada siswa yang dianggap sebagai individu paling lambat menerima pelajaran, dia mampu memberikan respon untuk mau aktif dalam pembelajaran.

Keberhasilan faktor kognitif sebuah media pembelajaran visual dibuktikan dengan temuan respon siswa yang cepat terhadap materi. Adanya 
temuan dari fungsi atensi maupun afeksi yang sudah dijelaskan pada point awal juga menjadi bagian dari keberhasilan fungsi kognitif untuk memicu reaksi dari siswa. Kemampuan belajar yang mampu ditunjukkan siswa setelah menerima pengalaman belajarnya sudah tentu termasuk dalam segala reaksi yang ditunjukkan siswa. Hal tersebut sesuai dengan pendapat Nana Sudjana (2009: 22) bahwa hasil belajar adalah kemampuan-kemampuan yang dimiliki siswa setelah ia menerima pengalaman belajarnya. Bukti kognitif lain dari keberhasilan fungsi kognitif media pembelajaran adalah hasil pretestpostest. Rata-rata nilai sebelum perlakuan adalah 51,67. Kemudian ada peningkatan hasil belajar yang dialami setelah treatment yang menunjukkan rata-rata nilai menjadi 93,33.

Gambar pada komik mampu mengganti suatu hal yang tidak mungkin dibawa dalam kelas. Materi fungsi alatalat tubuh merupakan materi pada IPA yang harus dibantu dengan adanya gambar-gambar organ tubuh. Gambar organ tubuh yang diberikan pada komik difungsikan untuk membantu siswa memahami letak-letak alat pernafasan yang berada di dalam tubuh. Gambar alat pernafasan pada komik sebagai alternatif bagi siswa untuk dapat melihat secara utuh organ pernafasan maupun bentuknya. Fakta tersebut sudah sesuai dengan fungsi media visual sebagai kompensatoris. Hal tersebut karena gambar alat-alat pernafasan manusia ataupun hewan mampu mengganti kehadiran alat-alat pernafasan asli yang tidak mungkin dibawa ke dalam kelas. Maka dari itu, gambar-gambar alat pernafasan mampu mengakomodasi kebutuhan kelengkapan pembelajaran untuk membantu siswa menerima dan memahami isi materi yang disajikan dengan teks pada komik atau secara verbal oleh guru.

Kelebihan komik jika dilihat dari aspek kontekstualnya adalah diperolehnya konsep pemberian pesan yang dapat membantu guru mengaitkan antara materi yang diajarkanya dengan situasi dunia nyata siswa. Dari hal tersebut pula dapat mendorong siswa membuat hubungan antara pengetahuan yang dimilikinya dengan penerapannya dalam kehidupan mereka. Pembelajaran kontekstual dirancang dan dilaksanakan berdasarkan landasan filosofis kontruktivisme yaitu filosofi belajar yang menekankan bahwa belajar tidak hanya sekedar menghafal. Siswa dapat mengkonstruksi pengetahuan di benak pikiran 
mereka, karena pada dasarnya pengetahuan tidak dapat dipisahpisahkan menjadi fakta atau proporsi yang terpisah dengan keterampilan yang bisa diterapkan.

Hasil dari penelitian ini adalah adanya pengaruh yang signifikan dari penggunaan media grafis komik terhadap prestasi belajar IPA siswa tunarungu pada materi fungsi alat-alat tubuh kelas V di SLB-B Pawestri Karanganyar tahun ajaran 2014/2015 dapat diterima kebenarannya. Pembelajaran IPA dengan menggunakan media grafis komik ini terbukti dapat meningkatkan prestasi belajar siswa tunarungu. Penggunaan media pembelajaran komik ini sebenarnya mempunyai potensi tidak hanya untuk ranah kognitif siswa tunarungu saja. Karakteristik dari komik yang bisa dikembangkan ke dalam berbagai bidang masih sangat terbuka untuk pengembangan media pembelajaran terkhusus untuk siswa tunarungu. Berawal dari komik tersebut, siswa tunarungu bisa dipacu untuk lebih giat membaca dan selanjutnya mereka bisa bertambah pengetahuannya.

Media pembelajaran komik mempunyai keunggulan antara lain dari aspek visual, aspek dunia anak dan juga aspek kontekstualitas konten sangat berpotensi untuk membuat pembelajaran bagi siswa tunarungu lebih aktif dan bermakna. Terlebih adanya aspek kontekstualitas yang dapat menjadikan suasana belajar lebih menyenangkan, siswa tidak merasa bosan, siswa dapat belajar secara aktif, guru bisa terbantu mengaitkan teori dengan kondisi nyata, dan menjadikan guru lebih kreatif.

\section{KESIMPULAN DAN SARAN}

Berdasarkan pembahasan hasil penelitian yang telah diuraikan, dapat disimpulkan bahwa penggunaan media grafis komik berpengaruh secara signifikan terhadap prestasi belajar IPA siswa tunarungu pada materi fungsi alatalat tubuh kelas V di SLB-B Pawestri Karanganyar tahun ajaran 2014/2015.

Berkaitan dengan hasil penelitian dan fakta di lapangan, maka peneliti dapat memberikan saran kepada pihakpihak yang terkait, sebagai berikut:

Dalam proses belajar mengajar hendaknya guru menggunakan pendekatan yang sesuai dengan karakteristik siswa khususnya anak tunarungu. Salah satu diantaranya adalah pengoptimalan penggunan media berbasis visual yaitu dengan menggunakan media grafis komik. Hal tersebut agar anak tunarungu 
dapat mengatasi permasalahannya dan aktif bereksplorasi karena didukung media pembelajaran yang sesuai dengan optimalisasi potensi visualnya.

Orang tua diharapkan dapat memberikan apresiasi, membantu dan memberikan dorongan kepada siswa untuk selalu mengulang materi yang diajarkan guru di sekolah agar dapat mengatasi kesulitan yang dialami.

\section{DAFTAR PUSTAKA}

Arshad, Azhar. (2007). Media Pembelajaran. Jakarta: Raja Grafindo Persada.

Avriliyanti, Herlina. (2012). Penerapan Media Komik Untuk Pembelajaran Fisika Model Kooperatif Dengan Metode Diskusi Pada Siswa SMP Negeri 5 Surakarta Kelas VII Tahun Ajaran 2011/2012 Materi Gerak. Skripsi Universitas Sebelas Maret Surakarta.

Masdiono, Toni (1998). Empat Belas Jurus Membuat Komik Jakarta: Creative Media Jakarta.

Riska Dwi Novianti dan M Syaichudin. (2010). Pengembangan Media Pembelajaran Komik Matematika Untuk Meningkatkan Pemahaman Bentuk Soal Cerita Bab Pecahan Pada Siswa Kelas V SDN Ngembung. Jurnal Teknologi Pendidikan, Vol.10, No.01: 7485.

Sadja'ah, Edja. (2013). Bina Bicara, Persepsi Bunyi dan Irama. Bandung: Refika Aditama.

Sanjaya, Wina. (2008). Kurikulum dan pembelajaran. Jakarta : Kencana Premada Media group.

Sudjana, Nana.(2009). Penilaian Hasil Proses Belajar Mengajar. Bandung: PT Remaja Rosdakarya.

Sugiyono.(2013). Metode Penelitian Kuantitatif, Kualitatif, R\&D, Bandung: CV. Alfabeta, 2013.

Trianto. (2010). Model Pembelajaran Terpadu. Jakarta: PT. Bumi Aksara.

Usman Samatowa. (2011). Pembelajaran IPA di Sekolah Dasar. Jakarta: PT Indeks. 